\title{
Preclinical Toxicity Evaluation of Quassia amara Extract with Potential Antimycobacterial Activity
}

\author{
Vinicius P. Arantes ${ }^{1}$, Guilherme L. Emerick ${ }^{1,2 *}$, Lais Silva Fernandes ${ }^{2}$, Ivan O. Pereira ${ }^{1}$ and Georgino H. DeOliveira ${ }^{1}$
}

${ }^{1}$ Department of Natural Active Principles and Toxicology, School of Pharmaceutical Science, Univ Estadual Paulista - UNESP, Araraquara, SP, Brazil ${ }^{2}$ Departamento de Análises Clínicas, Toxicológicas e Bromatológicas, Faculdade de Ciências Farmacêuticas de Ribeirão Preto-USP, Ribeirão Preto, SP, Brazil

\begin{abstract}
This study aimed to evaluate the oral acute and sub chronic toxicity of Quassia amara (Q. amara) extract. For the acute toxicity study, six male and six female rats received 2000 and $5000 \mathrm{mg} / \mathrm{kg} \mathrm{Q}$. amara extract. Rats were observed for 14 days; after sacrifice, liver, kidneys, lung, spleen and heart were submitted to macroscopic analysis. No death occurred and just the liver presented significant difference compared to the control group. For subchronic toxicity, eight groups of 6 male and 6 female rats received 200, 400 and $800 \mu \mathrm{g} / \mathrm{mL}$ of extract of $Q$. amara. Prothrombin time, bilirubin, urea, creatinine and gamma glutamyl transpeptidase ( $\gamma-\mathrm{GT}$ ), aspartate transaminase (AST), alanine transaminase (ALT) and alkaline phosphatase (ALP) were used as markers of renal and hepatobiliary function, respectively. The male showed a slight rise in serum bilirubin and creatinine and the female slight rise of AST, ALT and ALP activities. The urinalyses ( $\mathrm{pH}$, density, glucose and leukocytes) showed no change relative to the control. The NOAEL of $35 \mathrm{mg} / \mathrm{kg}$ and RfD $0.35 \mathrm{mg} / \mathrm{kg} /$ day encourage us to isolate the active principles in order to discover which molecules of this extract showed better antimycobacterial activity.
\end{abstract}

Keywords: Extract of Quassia amara; Assessment of toxicity; Mycobacterium tuberculosis; Mycobacterium avium; NOAEL; Reference dose

Abbreviations: LOAEL: Lowest Observed Adverse Effect Level; NOAEL: No Observed Adverse Effect Level; RfD: Reference Dose; MABA: Microplate Alamar Blue Assay; OECD: Organization for Economic Cooperation and Development; AST: Aspartate aminotransferase; ALT: Alanine aminotransferase; $\gamma$-GT: gamma Glutamyl Transpeptidase; ALP: Alkaline Phosphatase; MIC: Minimal Inhibitory Concentration; PT: Prothrombin Time; BRB: Bilirubin; BUN: Blood Urea Nitrogen; RBC: Red Blood Cell; Plt: Platelet; MCV: Mean Corpuscular Volume; MCH: Mean Corpuscular Hemoglobin; MCHC: Mean Cell Hemoglobin Concentration; Hb: Hemoglobin; Ht: Hematocrit; Q amara: Quassia amara

\section{Introduction}

Mycobacterium tuberculosis (MTB), the pathogenic agent of tuberculosis (TB), is responsible for the death of 2-3 million people annually and for a global economic toll of US\$12 billion each year [1]. Additionally, Mycobacterium avium is the most common cause of human infection due to non Tuberculous mycobacteria. Initially $M$. avium was regarded as only an opportunistic pathogen, primarily in Acquired Immunodeficiency Syndrome (AIDS) patients. However, it has now been shown to cause progressive pulmonary disease even in immunocompetent humans [2].

For the treatment of tuberculosis, the United States Food and Drug Administration (FDA), currently cites 10 medicines, divided into two lines of treatment. The treatment of first line consists of: isoniazid, rifampicin and pyrazinamide. The treatment of second line consists of: ethambutol and rifabutin. According to Zhang et al. [3] isoniazid and all other drugs in the first line show significant toxicity with adverse effects such as psychosis, convulsion and increase in hepatic enzymatic activity [Aspartate transaminase (AST), Alanine transaminase (ALT) and alkaline phosphatase (ALP)]. Rifampicin is also reported to cause hepatitis, leucopenia and induces the activity of hepatic microsomic enzymes. The frequent use of this drug can cause acute interstitial nephritis, glomerulonephritis and proteinuria $[4,5]$. The fact that the main drugs listed for the treatment of tuberculosis can have strong adverse effects, justifies the search for new medicines that offer at least the same effectiveness, but with less adverse effect.

An approach to the search for new drugs is to look in nature, mainly for the extremely rich and varied flora of the tropical areas. In this search, information obtained from folk knowledge and traditional medicine of different cultures can be valuable. This trend in associating popular or alternative medicine with pharmaceutical research has been growing for some years [6]. However, even though the activity of a popular plant medicine may be known, as well as the form in which it should be used, it is still necessary to prove its harmlessness, in order to diminish the risks to health. Moreover, it must be considered that one medicinal plant may not only show an immediate effect, easily correlated with its ingestion, but also sub chronic and chronic effects $[7,8]$.

The Simaroubaceae family has approximately 30 genus and 200 species. These plants are distributed across all the American continents, with greater abundance in tropical regions. The best known representative of this family is the Q. amara a large shrub between 3 and 8 meters in height, with palmate leaves of five leaflets, abrupt acuminate at apex and attenuated at base. Q. amara is popularly known as Muruba, Marupa, Quina de caiena in Portuguese $[9,10]$ and stave wood in English. Amongst the active principles of Q. amara, quassinoids

*Corresponding author: Guilherme L. Emerick, Departamento de Análises Clínicas, Toxicológicas e Bromatológicas, Faculdade de Ciências Farmacêuticas de Ribeirão Preto-USP, Avenida do Café, s/n, Monte Alegre, 14040-903, Ribeirão Preto, SP, Brazil, Tel: +55-16-3602-0656; Fax: +55-16-3602-4725; E-mail: glemerick@yahoo.com.br

Received November 15, 2012; Accepted November 22, 2012; Published Novemebr 26, 2012

Citation: Arantes VP, Emerick GL, Fernandes LS, Pereira IO, DeOliveira GH (2012) Preclinical Toxicity Evaluation of Quassia amara Extract with Potentia Antimycobacterial Activity. J Bioanal Biomed S5: 004. doi:10.4172/1948-593X.S5004

Copyright: (c) 2012 Arantes VP, et al. This is an open-access article distributed under the terms of the Creative Commons Attribution License, which permits unrestricted use, distribution, and reproduction in any medium, provided the original author and source are credited. 
constitute a class of chemicals found almost exclusively in plants of the Simaroubaceae family. These chemicals are oxygenated biodegradable triterpenes and they have a wide range of biological activity. Among the biological activities cited for quassinoids are anticancer, antimalarial, herbicidal, insecticidal, nematicidal, antitubercular and others. Thus, in popular medicine, the best known uses for Q. amara bark and wood are against flatulence, diarrhea, anemia, dyspepsia, malaria, and stomach [11]. In a previous work was presented an in vitro screening against Mycobacterium genera of a series of plants, demonstrated that Q. amara inhibited the growth of bacilli with a minimal inhibitory concentration (MIC) of $62.5 \mu \mathrm{g} / \mathrm{Ml}[12]$.

As the standard drugs for the treatment of tuberculosis have strong adverse effects on the liver and kidney, the objectives of this study was to determine the toxicity (in rats) of a daily preclinical dose of aqueous extract of Q. amara from Brazilian shrubby savannah giving special attention to the hepatobiliary and renal systems.

\section{Material and Methods}

\section{Plant material}

The Bark of Q. amara was collected in the savannah region of the State of South Mato Grosso, at Bataguassu $21^{\circ} 42^{\prime} 51^{\prime \prime} \mathrm{S}$ by $52^{\circ} 25^{\prime \prime}$ $20^{\prime} \mathrm{W}$, and the State of Goiás, at Rio Verde $17^{\circ} 47^{\prime \prime} 53^{\prime} \mathrm{S}$ by $51^{\circ} 55^{\prime \prime}$ $53^{\prime} \mathrm{W}$ from March to June of 2006. The material was placed in plastic bags, conditioned in Styrofoam boxes with ice and the bags stored in a freezer at $-20^{\circ} \mathrm{C}$ until the moment of use. The coordinates of this plant is also recorded in Toma et al. [13].

\section{Extraction and isolation}

The bark was washed in a current of water and then transferred to a drying greenhouse at a temperature of $40^{\circ} \mathrm{C}$, with constant movement. The bark was then triturated and transferred to an Erlenmeyer flask containing dichloromethane at final concentration of $500 \mathrm{~g} / \mathrm{L}$. Flasks were covered and wrapped in aluminum paper to protect them from light and were rocked for 72 hours. After this period, liquid fraction was filtered in a Buchner funnel and transferred to a rotating evaporator under reduced pressure and protected from light. The solid part was returned to the Erlenmeyer where dichloromethane was added again to carry out a new extraction (this operation was repeated four times). The concentrated extract was transferred to a heating plate at $40^{\circ} \mathrm{C} \pm$ 1 for four hours to evaporate the remaining solvent. The dried extract was mixed with $5 \%$ tween- $80(\mathrm{v} / \mathrm{v})$, enabling the dissolution of $250 \mathrm{mg}$ of extract per $\mathrm{ml}$ in distilled water. This stock solution was stored in a freezer $\left(-20^{\circ} \mathrm{C}\right)$ until used. From the stock solution, dilutions of 1200 , 800,400 and $200 \mu \mathrm{g} / \mathrm{mL}$ were prepared for oral administration to the test animals.

\section{Toxicity}

The experiments were carried out according to the protocols of the Organization for Economic Cooperation and Development (OECD 423 and 408) $[14,15]$. Wistar rats (60-day-old) were housed in plastic cages 30 (width) $\times 40$ (length) $\times 20$ (height) $\mathrm{cm}$ with shaving for acute toxicity (six per cage) and in metabolic cages for sub chronic toxicity (one per cage) in a climate controlled room at a temperature of $24^{\circ} \mathrm{C} \pm 2$, and relative humidity $55 \% \pm 10$, with light-dark cycle of 12 hours (light on at seven a.m.), with free access to tap water (for acute toxicity tests) and commercial food. All experimental procedures were conducted with the approval of the Research Ethics Committee of the School of Pharmaceutical Sciences of Araraquara, SP, Brazil in accordance with their guidelines for the care and use of laboratory animals (Resolution 44/ 2006).

Acute toxicity: Applying the oral limit test (as described by Protocol OECD 423) [14], all the doses of Q. amara extract were administered by gavage after overnight fasting in the morning, between 7 and 8 a.m. Two groups of six male rats and two groups of six female received a dose of 2000 and a dose of $5000 \mathrm{mg} / \mathrm{kg} /$ body weight of the Q. amara extract and two control groups of six male and six female rats received a solution of $5 \%$ Tween- $80(\mathrm{v} / \mathrm{v})$ in water. The animals were observed after the gavage at half an hour, $1 \mathrm{~h}, 2 \mathrm{~h}, 4 \mathrm{~h}, 8 \mathrm{~h}, 24 \mathrm{~h}$ and then daily for 14 days, when they were sacrificed. Liver, kidneys, lungs, spleen and heart were weighed, dissected and examined macroscopically. To calculate the relative weight we used the follow equation: [(organ weight $\times 100) /($ body weight)].

Sub chronic toxicity: After one week of acclimatization in individually metabolic cages (for individually assessment of urine), 20 male and 20 female rats, weighing on average 200 grams (initially) were divided into eight equal groups, six experimental and two controls. The animals received concentrations of 200,400 and $800 \mu \mathrm{g} / \mathrm{mL}$ (highest concentration of $Q$. amara in the palatability test at which rats did not diminish the ingestion in relation to the control) of Q. amara extract in their drinking water. To assess the volume of intake, the extracts of the plant was maintained for 7 days in place of drinking water, in increasing concentrations. No differences were observed between the intake of control (water) and ingestion of the extract analyzed, until the concentration of $800 \mu \mathrm{g} / \mathrm{ml}$. At higher concentration $(1200 \mu \mathrm{g} / \mathrm{ml})$, intake of the extract was reduced when compared with drinking water, characterizing the unacceptability of palatability. The control groups received only drinking water and the extracts were changed every three days (because the stability of the extract). The animals were observed during 90 days. After this period, the animals were sacrificed and blood was collected (in tubes with EDTA) by cardiac puncture. The following parameters were evaluated: full blood count; assay of the enzymes ALP, AST, ALT, gamma glutamyl transpeptidase ( $\gamma$-GT); analysis of the plasma levels of bilirubin, urea, creatinine, estimation of prothrombin time (using a clinical chemistry kit Liquiform Labtest); and assessment of the hepatic and renal profiles. Spleen, heart and lung were removed for macroscopic inspection while liver and kidneys were analyzed microscopically. For histopathological assessment, the liver and kidneys portions was gently dissected and immersion-fixed in $10 \%$ neutral buffered formalin for 48 hours. The tissues were then processed, embedded in paraffin, sectioned at $5 \mu \mathrm{m}$, and stained with hematoxylin and eosin ( $\mathrm{H} \& \mathrm{E})$. Urinalyses of the animals were carried out for $\mathrm{pH}$, density, glucose and leukocytes in the first and last weeks of the experiment.

Statistical analysis: Differences in biochemical parameters between groups were examined for statistical significance using ANOVA (Analysis of Variance), followed by Tukey's test for multiple comparisons. These tests were run in Microsoft Office Excel 2007 for Windows. The criterion of significance was $\mathrm{p}<0.05$ for all statistical analyses. All biochemical data are expressed as mean \pm standard error mean (SEM).

\section{Results}

\section{Acute toxicity}

The animals that received $2000 \mathrm{mg} / \mathrm{kg} /$ body weigh of Q. amara extract showed irritability in two male and three female rats; for the 
Citation: Arantes VP, Emerick GL, Fernandes LS, Pereira IO, DeOliveira GH (2012) Preclinical Toxicity Evaluation of Quassia amara Extract with Potential Antimycobacterial Activity. J Bioanal Biomed S5: 004. doi:10.4172/1948-593X.S5-004

Page 3 of 6

$5000 \mathrm{mg} / \mathrm{kg} /$ body weight dose, irritability was also observed in three male and two female until 2 days after ingestion of the extract. No deaths occurred during the 14 days of the trial. The dissected organs (heart, lung, spleen and kidney) exhibited relative weights and macroscopic appearance perfectly within the standards of normality. Only the liver decreased statistically different values of relative weight (dose of 5000 $\mathrm{mg} / \mathrm{kg} / \mathrm{body}$ weight) from control animals (Figures $1 \mathrm{a}$ and $\mathrm{lb}$ ).

\section{Subchronic toxicity}

For animals that received different concentrations of the Q. amara extract no significant changes were found in hematological profiles compared with control group, as demonstrated by tables 2 and 4 . In relation to the biochemical results it was verified an increase in serum bilirubin levels in male that received the dose of $800 \mu \mathrm{g} / \mathrm{ml}$. In the case of female, significant differences were noted for AST and ALT that showed an increase in the group that received the dose of $800 \mu \mathrm{g} /$ $\mathrm{mL}$ as shown in tables 1 and 3. Histopathological findings showed no significant changes compared with the control group (Figures $2 \mathrm{a}$ and $2 \mathrm{~b})$. No significant changes were found in the urinalyses profiles of

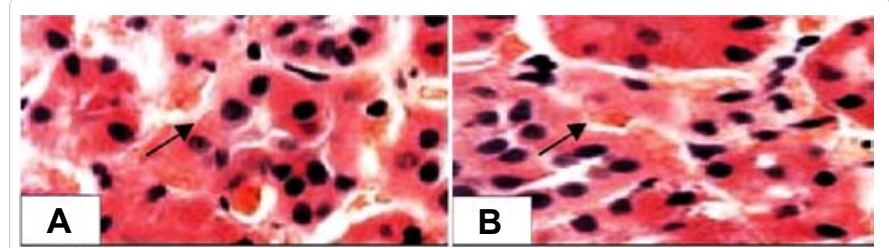

Figure 1a: A) Renal cortex of control rat, the arrow indicates the cell outlines. B) Renal Cortex of experimental rat treated with $800 \mu \mathrm{g} / \mathrm{ml}$ of extract of $Q$. amara in drinking water, after 90 days of exposure. The arrow indicates the comparison with the control with the normal cell outlines. No abnormality in the histoarchitecture of the kidney tissue can be seen (H \& E section 400x).
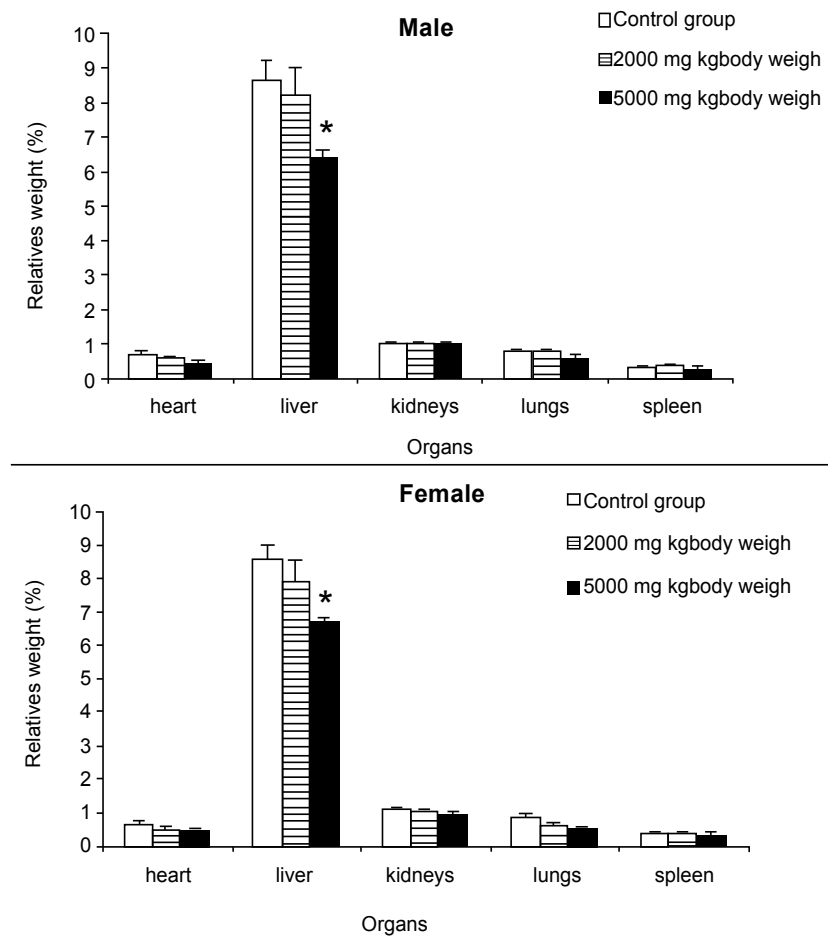

Figure 1b: Relative weight of the organs of Wistar rats subjected to acute toxicity test. The values are mean of five animals \pm standard error of mean. * Means statistically different from the control group at $p<0.05$.

\begin{tabular}{|c|c|c|c|c|}
\hline $\begin{array}{c}\text { Parameters } \\
\begin{array}{c}\text { Creatinine } \\
(\mathrm{mg} / \mathrm{dl})\end{array}\end{array}$ & $0.40 \pm 0.01$ & $\mathbf{2 0 0} \boldsymbol{\mu \mathbf { g } / \mathbf { m l }}$ & $\mathbf{4 0 0} \boldsymbol{\mu \mathrm { g } / \mathrm { ml }}$ & $\mathbf{8 0 0} \boldsymbol{\mu g} / \mathbf{m l}$ \\
\hline BUN (mg/dl) & $13.44 \pm 2.53$ & $14.52 \pm 1.87$ & $14.81 \pm 1.66$ & $14.91 \pm 1.66$ \\
\hline AST (IU/l) & $63.40 \pm 1.03$ & $64.80 \pm 1.46$ & $64.20 \pm 2.20$ & $66.80 \pm 1.11$ \\
\hline ALT (IU/l) & $13.97 \pm 2.14$ & $15.11 \pm 1.75$ & $15.71 \pm 3.27$ & $17.46 \pm 2.76$ \\
\hline Y-GT (IU/l) & $1.48 \pm 0.26$ & $1.70 \pm 0.26$ & $1.70 \pm 0.26$ & $1.91 \pm 0.21$ \\
\hline ALP (IU/l) & $30.40 \pm 2.76$ & $33.17 \pm 3.39$ & $35.93 \pm 3.39$ & $35.93 \pm 3.39$ \\
\hline $\begin{array}{c}\text { Bilirubin } \\
\text { (mg/dl) }\end{array}$ & $0.32 \pm 0.01$ & $0.35 \pm 0.01$ & $0.35 \pm 0.02$ & $0.38 \pm 0.01^{*}$ \\
\hline PT (s) & $6.20 \pm 0.37$ & $6.80 \pm 0.37$ & $6.80 \pm 0.37$ & $6.60 \pm 0.51$ \\
\hline
\end{tabular}

BUN blood urea nitrogen; AST aspartate aminotransferase; ALT alanine aminotransferase; $\quad$-GT gamma glutamyl transpeptidase; ALP alkaline phosphatase; PT prothrombin time.

$\mathrm{N}=5$ animals per group. The values are mean \pm standard error of mean.

* Means statistically different from the control group at $p<0.05$.

Table 1: Serum biochemical profile of Wistar male rats treated with different concentrations of crude Quassia amara extract through drinking water after 90 days of exposure.

\begin{tabular}{|c|c|c|c|c|}
\hline Parameters & Control & $200 \mu \mathrm{g} / \mathrm{ml}$ & $400 \mu \mathrm{g} / \mathrm{ml}$ & $800 \mu \mathrm{g} / \mathrm{ml}$ \\
\hline $\operatorname{RBC}\left(\times 10^{6} \mu \mathrm{l}\right)$ & $6.08 \pm 0.67$ & $6.08 \pm 0.26$ & $6.82 \pm 0.25$ & $5.91 \pm 0.49$ \\
\hline $\mathrm{Hb}(\mathrm{dl})$ & $10.78 \pm 1.09$ & $10.76 \pm 0.69$ & $11.96 \pm 0.51$ & $10.62 \pm 0.98$ \\
\hline $\mathrm{Ht}(\%)$ & $31.78 \pm 3.27$ & $32.14 \pm 1.85$ & $35.44 \pm 1.53$ & $30.74 \pm 2.62$ \\
\hline $\operatorname{MCV}(f l)$ & $52.58 \pm 0.89$ & $52.80 \pm 0.94$ & $51.96 \pm 0.46$ & $51.98 \pm 0.62$ \\
\hline $\mathrm{MCH}(\mathrm{pg})$ & $17.82 \pm 0.43$ & $17.64 \pm 0.40$ & $17.50 \pm 0.21$ & $17.90 \pm 0.43$ \\
\hline $\mathrm{MCHC}(\mathrm{g} / \mathrm{dl})$ & $33.94 \pm 0.50$ & $33.48 \pm 0.36$ & $33.70 \pm 0.18$ & $34.44 \pm 0.23$ \\
\hline \multirow[t]{2}{*}{ Plt. $\left(\times 10^{3} \mu \mathrm{l}\right)$} & $6.37 \pm 1.26$ & $6.86 \pm 0.56$ & $8.24 \pm 0.55$ & $7.07 \pm 0.64$ \\
\hline & \multicolumn{3}{|c|}{ Differential leukocyte count } & \\
\hline Mielocytes & $0.0 \pm 0.0$ & $0.0 \pm 0.0$ & $0.0 \pm 0.0$ & $0.0 \pm 0.0$ \\
\hline $\begin{array}{l}\text { Metamielo- } \\
\text { cytes }\end{array}$ & $0.0 \pm 0.0$ & $0.0 \pm 0.0$ & $0.0 \pm 0.0$ & $0.0 \pm 0.0$ \\
\hline Bastonetes & $0.0 \pm 0.0$ & $0.0 \pm 0.0$ & $0.0 \pm 0.0$ & $0.0 \pm 0.0$ \\
\hline Segmented & $13.00 \pm 0.5$ & $13.20 \pm 0.80$ & $12.6 \pm 0.40$ & $12.80 \pm 0.37$ \\
\hline Eosinophils & $0.0 \pm 0.0$ & $0.0 \pm 0.0$ & $0.20 \pm 0.20$ & $0.20 \pm 0.20$ \\
\hline Basophils & $0.0 \pm 0.0$ & $0.0 \pm 0.0$ & $0.0 \pm 0.0$ & $0.0 \pm 0.0$ \\
\hline Lymphocytes & $86.60 \pm 1.03$ & $86.60 \pm 0.51$ & $86.40 \pm 0.68$ & $86.60 \pm 1.03$ \\
\hline Monocytes & $0.40 \pm 0.25$ & $0.20 \pm 0.20$ & $0.40 \pm 0.25$ & $0.40 \pm 0.25$ \\
\hline
\end{tabular}

$\mathrm{RBC}$ red blood cells; $\mathrm{Hb}$ hemoglobin; Ht hematocrit; MCV mean corpuscular volume; $\mathrm{MCH}$ mean corpuscular hemoglobin; $\mathrm{MCHC}$ mean corpuscular hemoglobin concentration; Plt; platelet.

$\mathrm{N}=5$ animals per group. The values are mean \pm standard error of mean

Table 2: Serum hematological profile of Wistar male rats treated with different concentrations of crude Quassia amara extract through drinking water after 90 days of exposure.

any animals that received different concentration of Q. amara extract, comparing the first week with the last week of experiment, not even with the $800 \mu \mathrm{g} / \mathrm{ml}$ which was the highest concentration given to animals, (Table 5).

\section{Discussion}

The dichloromethane $Q$. amara extract tested before against $M$. avium and M. tuberculosis showed a MIC value of $62.5 \mu \mathrm{g} / \mathrm{ml}$. Tosun et al. [16] considered inactive the plant extracts that could not prevent growth of $M$. tuberculosis up to a concentration of $200 \mu \mathrm{g} / \mathrm{ml}$ and 
Citation: Arantes VP, Emerick GL, Fernandes LS, Pereira IO, DeOliveira GH (2012) Preclinical Toxicity Evaluation of Quassia amara Extract with Potential Antimycobacterial Activity. J Bioanal Biomed S5: 004. doi:10.4172/1948-593X.S5-004

Page 4 of 6

\begin{tabular}{|c|c|c|c|c|}
\hline Parameters & Control & $\mathbf{2 0 0} \boldsymbol{\mu g} / \mathbf{m l}$ & $\mathbf{4 0 0} \boldsymbol{\mu g} / \mathbf{m l}$ & $\mathbf{8 0 0} \mathbf{\mu g} / \mathbf{m l}$ \\
\hline $\begin{array}{c}\text { Creatinine } \\
(\mathrm{mg} / \mathrm{dl})\end{array}$ & $0.41 \pm 0.01$ & $0.40 \pm 0.01$ & $0.42 \pm 0.01$ & $0.43 \pm 0.02$ \\
\hline BUN (mg/dl) & $12.52 \pm 1.47$ & $15.82 \pm 1.35$ & $15.82 \pm 1.35$ & $15.94 \pm 1.47$ \\
\hline AST (IU/l) & $68.00 \pm 1.23$ & $72.00 \pm 1,23$ & $74.00 \pm 2.74$ & $78.00 \pm 3.0^{*}$ \\
\hline ALT (IU/l) & $13.97 \pm 2.14$ & $21.46 \pm 4.28$ & $24.44 \pm 4.28^{*}$ & $29.68 \pm 2.14^{*}$ \\
\hline Y-GT (IU/l) & $1.29 \pm 2.14$ & $1.52 \pm 0.28$ & $1.52 \pm 0.28$ & $1.98 \pm 0.23$ \\
\hline ALP (IU/l) & $30.40 \pm 5.17$ & $30.40 \pm 5.17$ & $33.17 \pm 3.38$ & $38.70 \pm 2.76^{*}$ \\
\hline $\begin{array}{c}\text { Bilirubin } \\
\text { (mg/dl) }\end{array}$ & $0.36 \pm 0.001$ & $0.37 \pm 0.01$ & $0.37 \pm 0.01$ & $0.37 \pm 0.01$ \\
\hline PT (s) & $6.80 \pm 0.20$ & $6.80 \pm 0.37$ & $7.20 \pm 0.37$ & $7.40 \pm 0.51$ \\
\hline
\end{tabular}

BUN blood urea nitrogen; AST aspartate aminotransferase; ALT alanine aminotransferase; Y-GT gamma glutamyl transpeptidase; ALP alkaline phosphatase; PT prothrombin time.

$\mathrm{N}=5$ animals per group. The values are mean \pm standard error of mean

${ }^{*}$ Means statistically different from the control group at $p<0.05$.

Table 3: Serum biochemical profile of Wistar female rats treated with different concentrations of crude extract of Quassia amara through drinking water after 90 days of exposure.

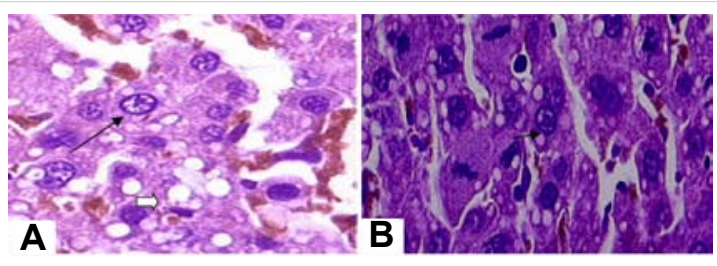

Figure 2a: A) Hepatic cortex of control rat, the arrow indicates the nucleus of the cell and accumulation of light lipids in its neighborhood. B) Hepatic cortex of experimental rat treated with $800 \mu \mathrm{g} / \mathrm{ml}$ of extract of $Q$. amara in drinking water after 90 days of exposure. The arrow indicates the comparison with the light accumulation of lipids near the normal control cell. No abnormality in the histoarchitecture of the liver tissue can be seen (H \& E section 400x).
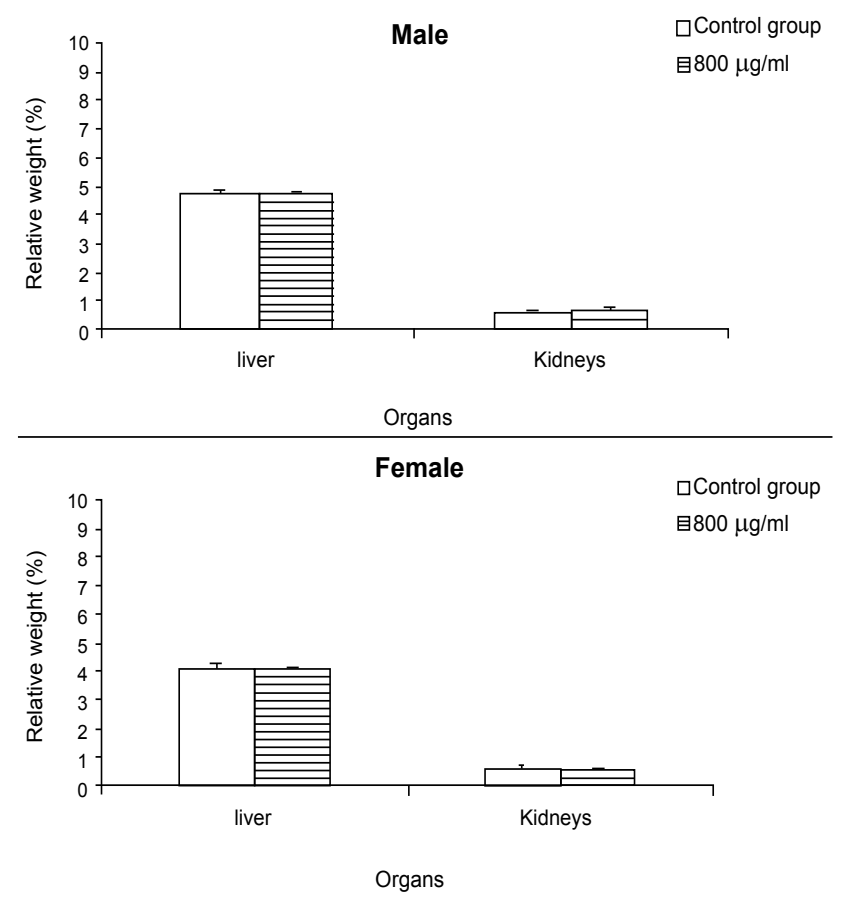

Figure 2b: Relative weight of the organs of Wistar rats subjected to subchronic toxicity test. The values are mean of five animals \pm standard error of mean. *Means statistically different from the control group at $p<0.05$.

\begin{tabular}{|c|c|c|c|c|}
\hline Parameters & Control & $200 \mu \mathrm{g} / \mathrm{ml}$ & $400 \mu \mathrm{g} / \mathrm{ml}$ & $800 \mu \mathrm{g} / \mathrm{ml}$ \\
\hline $\mathrm{RBC}\left(\mathrm{x} 10^{6} \mu \mathrm{l}\right)$ & $6.08 \pm 0.23$ & $6.81 \pm 0.25$ & $6.48 \pm 0.45$ & $6.24 \pm 0.70$ \\
\hline $\mathrm{Hb}(\mathrm{dl})$ & $11.02 \pm 0.85$ & $12.06 \pm 0.46$ & $11.68 \pm 0.38$ & $10.84 \pm 1.12$ \\
\hline $\mathrm{Ht}(\%)$ & $35.10 \pm 1.27$ & $35.64 \pm 1.43$ & $30.74 \pm 2.63$ & $34.42 \pm 1.15$ \\
\hline $\mathrm{MCV}(\mathrm{fl})$ & $53.38 \pm 1.27$ & $51.96 \pm 0.46$ & $51.98 \pm 0.62$ & $52.34 \pm 0.76$ \\
\hline $\mathrm{MCH}(\mathrm{pg})$ & $18.06 \pm 0.43$ & $17.72 \pm 0.22$ & $17.92 \pm 0.25$ & $18.04 \pm 0.43$ \\
\hline $\mathrm{MCHC}(\mathrm{g} / \mathrm{dl})$ & $33.72 \pm 0.16$ & $33.78 \pm 0.18$ & $34.28 \pm 0.25$ & $33,86 \pm 0.48$ \\
\hline \multirow[t]{2}{*}{ Plt. $\left(\times 10^{3} \mu \mathrm{l}\right)$} & $7.52 \pm 0.73$ & $8.34 \pm 0.56$ & $7.93 \pm 0.76$ & $6.27 \pm 1.25$ \\
\hline & \multicolumn{3}{|c|}{ Differential leukocyte count } & \\
\hline Mielocytes & $0.0 \pm 0.0$ & $0.0 \pm 0.0$ & $0.0 \pm 0.0$ & $0.0 \pm 0.0$ \\
\hline $\begin{array}{l}\text { Metamielo- } \\
\text { cytes }\end{array}$ & $0.0 \pm 0.0$ & $0.0 \pm 0.0$ & $0.0 \pm 0.0$ & $0.0 \pm 0.0$ \\
\hline Bastonetes & $0.0 \pm 0.0$ & $0.0 \pm 0.0$ & $0.0 \pm 0.0$ & $0.0 \pm 0.0$ \\
\hline Segmented & $12.00 \pm 0.32$ & $12.80 \pm 0.58$ & $12.80 \pm 0.58$ & $12.00 \pm 0.32$ \\
\hline Eosinophils & $0.0 \pm 0.0$ & $0.0 \pm 0.0$ & $0.40 \pm 0.25$ & $0.40 \pm 0.25$ \\
\hline Basophils & $0.0 \pm 0.0$ & $0.20 \pm 0.20$ & $0.0 \pm 0.0$ & $0.0 \pm 0.0$ \\
\hline Lymphocytes & $88.00 \pm 0.63$ & $86.00 \pm 0.86$ & $87.6 \pm 0.51$ & $87.20 \pm 0.58$ \\
\hline Monocytes & $0.0 \pm 0.0$ & $0.20 \pm 0.20$ & $0.0 \pm 0.0$ & $0.40 \pm 0.25$ \\
\hline
\end{tabular}

$\mathrm{RBC}$ red blood cells; $\mathrm{Hb}$ hemoglobin; Ht hematocrit; $\mathrm{MCV}$ mean corpuscular volume; $\mathrm{MCH}$ mean corpuscular hemoglobin; $\mathrm{MCHC}$ mean corpuscular hemoglobin concentration; PIt; platelet.

$\mathrm{N}=5$ animals per group. The values are mean \pm standard error of mean.

Table 4: Serum hematological profile of Wistar female rats treated with different concentrations of crude extract of Quassia amara through drinking water after 90 days of exposure.

according to $\mathrm{Gu}$ et al. [17] the MIC value of $128 \mu \mathrm{g} / \mathrm{ml}$ is defined as active. For Cantrell et al. [18], isolated compounds that exhibit a MIC of $64 \mu \mathrm{g} / \mathrm{ml}$ or lower are considered promising. Thus, the MIC value of $62.5 \mu \mathrm{g} / \mathrm{ml}$ presented by $Q$. amara extract is good as a promising isolated compounds and lower than the value established for other authors. The active compounds of the extract passed through the thick lipid rich cell wall of mycobacteria and show activity $[19,20]$.

Q. amara has been used for a long time in traditional medicine for diverse purposes [12] and the antimycobacterial results presented in other works provide a compelling reason to evaluate the toxicity of this extract in rats. In the acute toxicity test only slight irritability were observed in a few animals that received dose $\geq 2000 \mathrm{mg} / \mathrm{kg}$. This irritability did not last more than 2 days after extract ingestion. Macroscopic observations of the heart, lung, spleen, kidney and liver did not reveal any visible change. These results suggest that $Q$. amara extract has low acute oral toxicity, since in the dose limit test there was not a single death.

In the subchronic toxicity test the effect of $Q$. amara extract on the biochemical parameters for serum of male and female rats can be seen respectively in tables 1 and 3 . The rise in the creatinine and urea concentrations in the blood can be used as an index of decreased glomerular filtration [21]. In the present study, the creatinine results were normal in both male and female, irrespective of the extract concentration. Besides these parameters, the ALP activity remained unchanged in relation to the control, corroborating the idea of real integrity of the animals after administration of $Q$. amara extract. Stetinova et al. [22] demonstrated that the urinary elimination of cells is more sensitive to nephrotoxicity than the excretion of $\mathrm{N}$-acetyl $\beta$-D-glucoseamidase (NAG). In the present study, in the urine of 


\begin{tabular}{|c|c|c|c|c|c|c|c|c|c|c|}
\hline & \multicolumn{9}{|c}{ MALES } & \multicolumn{5}{c|}{ FEMALES } \\
\hline Animals & $\mathbf{1}$ & $\mathbf{2}$ & $\mathbf{3}$ & $\mathbf{4}$ & $\mathbf{5}$ & $\mathbf{1}$ & $\mathbf{2}$ & $\mathbf{3}$ & $\mathbf{4}$ & $\mathbf{5}$ \\
\hline Time of analysis & $\mathrm{fw}-\mathrm{Iw}$ & $\mathrm{fw}-\mathrm{Iw}$ & $\mathrm{fw}-\mathrm{Iw}$ & $\mathrm{fw}-\mathrm{Iw}$ & $\mathrm{fw}-\mathrm{Iw}$ & $\mathrm{fw}-\mathrm{Iw}$ & $\mathrm{fw}-\mathrm{Iw}$ & $\mathrm{fw}-\mathrm{Iw}$ & $\mathrm{fw}-\mathrm{Iw}$ & $\mathrm{fw}-\mathrm{Iw}$ \\
\hline Bilirubin & $\mathrm{N}-\mathrm{N}$ & $\mathrm{N}-\mathrm{N}$ & $\mathrm{N}-\mathrm{N}$ & $\mathrm{N}-\mathrm{N}$ & $\mathrm{N}-\mathrm{N}$ & $\mathrm{N}-\mathrm{N}$ & $\mathrm{N}-\mathrm{N}$ & $\mathrm{N}-\mathrm{N}$ & $\mathrm{N}-\mathrm{N}$ & $\mathrm{N}-\mathrm{N}$ \\
\hline $\mathrm{RBC}$ & $\mathrm{A}-\mathrm{A}$ & $\mathrm{A}-\mathrm{A}$ & $\mathrm{A}-\mathrm{A}$ & $\mathrm{A}-\mathrm{A}$ & $\mathrm{A}-\mathrm{A}$ & $\mathrm{A}-\mathrm{A}$ & $\mathrm{A}-\mathrm{A}$ & $\mathrm{A}-\mathrm{A}$ & $\mathrm{A}-\mathrm{A}$ & $\mathrm{A}-\mathrm{A}$ \\
\hline $\mathrm{pH}$ & $5-5$ & $5-5$ & $5-5$ & $6-6$ & $6-6$ & $6-6$ & $5-5$ & $6-6$ & $6-6$ & $5-5$ \\
\hline Nitrite & $\mathrm{A}-\mathrm{A}$ & $\mathrm{A}-\mathrm{A}$ & $\mathrm{A}-\mathrm{A}$ & $\mathrm{A}-\mathrm{A}$ & $\mathrm{A}-\mathrm{A}$ & $\mathrm{A}-\mathrm{A}$ & $\mathrm{A}-\mathrm{A}$ & $\mathrm{A}-\mathrm{A}$ & $\mathrm{A}-\mathrm{A}$ & $\mathrm{A}-\mathrm{A}$ \\
\hline Density & 1.015 & 1.015 & 1.015 & 1.015 & 1.015 & 1.010 & 1.010 & 1.010 & 1.015 & 1.010 \\
\hline Acetone & 1.015 & 1.015 & 1.015 & 1.015 & 1.015 & 1.010 & 1.010 & 1.010 & 1.015 & 1.010 \\
\hline Glucose & $\mathrm{A}-\mathrm{A}$ & $\mathrm{A}-\mathrm{A}$ & $\mathrm{A}-\mathrm{A}$ & $\mathrm{A}-\mathrm{A}$ & $\mathrm{A}-\mathrm{A}$ & $\mathrm{A}-\mathrm{A}$ & $\mathrm{A}-\mathrm{A}$ & $\mathrm{A}-\mathrm{A}$ & $\mathrm{A}-\mathrm{A}$ & $\mathrm{A}-\mathrm{A}$ \\
\hline Leukocyte & $\mathrm{N}-\mathrm{N}$ & $\mathrm{N}-\mathrm{N}$ & $\mathrm{N}-\mathrm{N}$ & $\mathrm{V}$ & $\mathrm{N}-\mathrm{N}$ & $\mathrm{V}$ & $\mathrm{V}$ & $\mathrm{V}$ & $\mathrm{N}-\mathrm{N}$ & $\mathrm{N}-\mathrm{N}$ \\
\hline
\end{tabular}

$\mathrm{FW}=$ first week; $\mathrm{LW}=$ last week; $\mathrm{A}=$ absent; $\mathrm{N}=$ normal; $\mathrm{RBC}=$ red blood cells

Table 5: Urinalysis profile of Wistar male and female rats treated with $800 \mu \mathrm{g} / \mathrm{ml}$ of crude Quassia amara extract through their drinking water after 90 days of exposure.

rats, neither cells under microscopic was observed nor alterations in physico-chemical parameters as $\mathrm{pH}$, density and glucose were detected. These findings suggest that this extract of Q. amara did not interfere with the normal functioning of the kidneys.

Many authors use the serum activity of enzymes such as $\gamma$-GT, AST, and ALT to assess hepatocellular injury [23,24]. More specifically, Vetelainen et al. [25] used the plasma bilirubin level to assess indirectly the hepatic metabolic and excretory function, and the prothrombin time (PT) to evaluate the capacity for hepatocyte protein synthesis. In the present study, levels of activity of ALT, AST, $\gamma$-GT and PT were determined to assess the hepatobiliar toxicity. In male rats, only bilirubin showed a significant increase in relation to the control at the concentration of $800 \mu \mathrm{g} / \mathrm{ml}$. As no other parameter to use to test the tissue or hepatic function was modified, this suggests that the $Q$. amara extract did not cause hepatotoxicity in male rats. With regard to the female rats, a statistically significant rise of AST and ALT activity was observed only at the $800 \mu \mathrm{g} / \mathrm{ml}$ concentration. As the plasma bilirubin level was still normal, it is possible that hepatic function was also normal yet. However, this data may be showing that the female rats were a little more sensitive than the male rats. In addition, the 800 $\mu \mathrm{g} / \mathrm{ml}$ concentration may be considered the lowest observed adverse effect level (LOAEL) for female rats. Biochemically defined, cholestase consists of altered serum constituents that are hyperbilirubinemia, bile acidemia, and elevated enzymes activity such as ALP and $\gamma$-GT $[26,27]$. In the present study, although there was a rise in the serum bilirubin level for the males, no other parameter was altered, while the females did not suffer alteration of any of these three parameters, excluding the presence of cholestasis.

Both for male and female there were no changes in normal hematological parameters, as can be seen in tables 2 and 4 . Also, there was no evidence of noteworthy histopathological change relative to the controls, when the various concentrations of the extract were compared.

Taking as end-point the hepatic biochemical changes that were the most sensitive, a concentration of $400 \mu \mathrm{g} / \mathrm{ml}$ of Q. amara extract did not cause any adverse effect in male or female. Considering that the animals ingested an average of $26.5 \mathrm{ml}$ of extract per day and weighed on average (initial weight+final weight/2) 303 grams, and using the concentration of $400 \mu \mathrm{g} / \mathrm{ml}$, the no observed adverse effect level (NOAEL) was $35 \mathrm{mg} / \mathrm{kg}$ body weight per day. On the basis of this
NOAEL, it can be inferred that the reference dose (RfD) would be 0.35 $\mathrm{mg} / \mathrm{kg}$ body weight per day with a safety factor of 100 .

Concluding, the Q. amara that is widely used in popular medicine demonstrated low acute and subchronic hepatic and renal toxicity. These data encourages us to continue this work by bioassay guided fractionation with purpose of identifying the purified fraction or pure compound responsible for the antimycobacterial activity.

\section{Acknowledgments}

The authors are deeply grateful to Adriana Tomo and Maria Aparecida dos Santos Francisco for their technical support. The financial support for this work was provided by FUNDUNESP Fundação para o Desenvolvimento da UNESP Grant \# 00043/08-DFP and School of Pharmaceutical Science Univ Estadual Paulista - UNESP.

\section{References}

1. http://www.tballiance.org/why/economic-impact.php

2. Tateishi Y, Hirayama Y, Ozeki Y, Nishiuchi Y, Yoshimura M, et al (2009) Virulence of Mycobacterium avium complex strains isolated from immunocompetent patients. Microb pathog 46: 6-12.

3. Zhang ZH, Tang JH, Zhan ZL, Zhang XL, Wu HH, et al. (2012) Cellular toxicity of isoniazid together with rifampicin and the metabolites of isoniazid on QSG7701 hepatocytes. Asian Pac J Trop Med 5: 306-309.

4. Parthasarathy R, Sarma GR, Janardhanam B, Ramachandran P, Santha T, et al. (1986) Hepatic toxicity in South Indian patients during treatment of tuberculosis with short-course regimens containing isoniazid, rifampicin and pyrazinamide. Tubercle 67: 99-108.

5. Saad El, El-Gowilly SM, Sherhaa MO, Bistawroos AE (2010) Role of oxidative stress and nitric oxide in the protective effects of alpha-lipoic acid and aminoguanidine against isoniazid-rifampicin-induced hepatotoxicity in rats. Food Chem Toxicol 48: 1869-1875.

6. Cooper EL (2004) Drug Discovery, CAM and Natural Products. Evid Based Complement Alternat Med 1: 215-217.

7. Abbott PJ (1988) Comfrey: assessing the low-dose health risk. Med J Aust 149: $678-682$.

8. Yeong ML, Wakefield SJ, Ford HC (1993) Hepatocyte membrane injury and bleb formation following low dose comfrey toxicity in rats. Int $\mathrm{J}$ exp pathol 74 : 211-217.

9. Thomas WW (1990) The American genera of Simaroubaceae and their distribution. Acta Bot Bras 4:11-18.

10. Macedo EG, Potiguara RCV, Neto OR (2005) Anatomia foliar de Quassia amara L. (Simaroubaceae) uma espécie medicinal e inseticida. Boletim do Museu Paraense Emílio Goeldi Ciências Naturais 1: 9-18. 
Citation: Arantes VP, Emerick GL, Fernandes LS, Pereira IO, DeOliveira GH (2012) Preclinical Toxicity Evaluation of Quassia amara Extract with Potential Antimycobacterial Activity. J Bioanal Biomed S5: 004. doi:10.4172/1948-593X.S5-004

11. Almeida MMB, Arriaga AMC, Santos AKL, Lemos TLG, Filho RB, et al. (2007) Ocorrência e atividade biológica de quassinóides da última década. Quimica nova 30: 935-951.

12. Arantes VP, Sato DN, Vilegas W, Santos LC, Leite CQF (2005) Plantas do cerrado brasileiro com atividade contra Mycobacterium fortuitum. Rev Ciênc Farm Básica 26:195-198.

13. Toma W, Gracioso Jde S, de Andrade FD, Hiruma-Lima CA, Vilegas W, et al. (2002) Antiulcerogenic activity of four extracts obtained from the bark wood of Quassia amara L. (Simaroubaceae). Biol Pharm Bull 25: 1151-1155.

14. http://www.intermed.it/istbiotech/reach/B01trisweb2004.pdf

15. Test No. 408: Repeated Dose 90-Day Oral Toxicity Study in Rodents (1998) OECD Publishing

16. Tosun F, Kizilay CA, Sener B, Vural M, Palittapongarnpim P (2004) Antimycobacterial screening of some Turkish plants. Journal of ethnopharmacology 95: $273-275$

17. Gu JQ, Wang Y, Franzblau SG, Montenegro G, Yang D, et al. (2004) Antitubercular constituents of Valeriana laxiflora. Planta med 70: 509-514.

18. Cantrell CL, Franzblau SG, Fischer NH (2001) Antimycobacterial plan terpenoids. Planta Med 67:685-694.

19. Aguiar RM, David JP, David JM (2005) Unusual naphthoquinones, catechin and triterpene from Byrsonima microphylla. Phytochemistry 66: 2388-2392.

20. Pavan FR, Sato DN, Higuchi CT, Santos ACB, Vilegas W, et al. (2009) In vitro anti-Mycobacterium tuberculosis activity of some Brazilian "Cerrado" plants. Rev Bras farmacogn 19: 204-206.
21. Akdogan M, Kilinc I, Oncu M, Karaoz E, Delibas N (2003) Investigation of biochemical and histopathological effects of Mentha piperita L. and Mentha spicata L. on kidney tissue in rats. Hum Exp Toxicol 22: 213-219.

22. Stetinova V, Trejtnar F, Kopecky J, Grossmann V, Kvetina J, et al. (1996) Possible use of excretion of tubular epithelial cells for the study of the nephrotoxic effect of xenobiotics. Journal of pharmacological and toxicological methods 36: 199-204.

23. Smink F, van Hoek B, Ringers J, van Altena R, Arend SM (2006) Risk factors of acute hepatic failure during antituberculosis treatment: two cases and literature review. Neth J Med 64: 377-384.

24. Takahashi M, Yoshida M, Inoue K, Morikawa T, Nishikawa A (2009) A ninetyday toxicity study of semicarbazide hydrochloride in Wistar Hannover GALAS rats. 47: 2490-2498.

25. Vetelainen RL, Bennink RJ, de Bruin K, van Vliet A, van Gulik TM (2006) Hepatobiliary function assessed by $99 \mathrm{mTc}$-mebrofenin cholescintigraphy in the evaluation of severity of steatosis in a rat model. Eur $\mathrm{J}$ Nucl Med Mol Imaging 33: $1107-1114$

26. Arantes-Rodrigues R, Henriques A, Pires MJ, Colaco B, Calado AM, et al. (2011) High doses of olive leaf extract induce liver changes in mice. Food Chem Toxicol 49: 1989-1997.

27. da Costa LL, Albano F, Augusto TLG, Marques Alves L, Fernando Martins $\mathrm{SL}$, et al. Toxicological evaluation by in vitro and in vivo assays of an aqueous extract prepared from Echinodorus macrophyllus leaves. Toxicol lett 116: 189198. 